\title{
ATATÜRK DöNEMINDE SOSYAL POLITIKA
}

\author{
Prof. Dr. Sait DiLİK
}

Osmanlı İmparatorluğu sanayi devrimiyle Avrupa'da gerçekleşen ekonomik gelişimlere ayak uyduramamış ve bu nedenle Imparatorlukta dikkati çeken bir iş̧̧i kitlesi oluşmamıştı. Bu nedenle Imparatorlukta sosyal politika tedbirlerine önem verilmemiş; dikkati çekecek bir kitle oluşturmamıs olsalar da, mevcut iş̧ilerin korunmasına yönelik sosyal içerikli kanunlar çıkarılamamıştı.

İmparatorlukta işçi işveren ilişkileri, 19. Yüzyılın ikinci yarısında zamanin borçlar kanunu olan 1860 tarihli mecelle ile düzenlenmişti. Mecelle zamanın koşullarına göre, hukuk düzeninde pozitif hukukun kurulması yönünde ileri bir adım teşkil etmekle birlikte, iş̧i işveren ilişkileri konu.sundaki düzenlemeleri bakımından yeterli olmaktan uzaktı. Mecelle bireyci ve aşım liberal bir nitelik taşımaktaydı. Mecellede işçi işveren ilişkileri "icare-i ademi" yani insanın kiraya verilmesi başlı̆̆ı altında ele alınmış; iş̧i de, Roma Hukukunda olduğu gibi, nefsini kiraya veren insan olarak tanımlanmıştı.

İmparatorlukta bunun dışında çalışma ilişkilerini düzenleyen herhangi bir kanun bulunmamaktayd. Sadece nispeten yoğun bir kitlenin çalıştığı maden sektöründe uygulanmış olan 1863 tarihli "Maden Nizamnamesi", 1865 tarihli Dilaver Paşa Nizamnamesi ve 1869 tarihli Maadin "Nizamnamesi" isimli tüzükler vardı. Bunlar arasında dönemine göre ileri normlar getirmiş olanı Maadin Nizamnamesiydi. Bu nizamnamede zorunlu çalışma yasaklanmakta, iş̧̧i sağlığının korunması, iş güvenliğinin sağlanmasıyla, iş̧̧ye işverenlerce iş kazaları durumunda tazminat ödenmesine ilişkin hükümler bulúnmaktayd. Dilaver Paşa Nizamnamesi* ise işçiyi korumaktan çok üretimi artırma amacına yönelikti ve zorunlu çaIışma esasını benimsemişti.

- Dilaver Paşa Nizamnamesi gerçekte gerekli onaycian geçmediği için nizamname yani tüzük niteliğini almamıştı; ancak, Ereğli Kömür Madenlerinin yönetim sorumluluğunu yüklenmiş olan Dilaver Paşa tarafından hazırlanmıs bir tüzük tar sarısı olarak, bölgede fiilen uygulanmış olduğundan bu ismi almıştı. Ekin bu Nizamnamenin uygulanmamış olduğu görüşündedir. Bkz:: N. Ekin, Endüstri llişkileri, Istanbul 1876, s. 226. 
Meşrutiyetin ilanından sonra, siyasal faktörlerin de etkisiyle, imparatorlukta, ağır çalışma koşullarına karşı bir grev dalgasının esmeye başladığı görülmüş; bu grev hareketleri "İttihat ve Terakki" iktidarınca 1909 tarihli Tatil-i Eşgal Kanunur:un çıkarılmasına yol açmıştır. Bu kanunla kamu hizmeti gören işyerlerinde sendika kurulması ve grev yapılması yasaklanmiştır.

Atatürk'ün gerçekleştirdiği Yeni Türk Devleti daha kuruluşunun ilk günlerinde iş̧i sorunlarına karş̧ büyük bir ilgi duymuştu. Kurtuluş Savaşı yürütülürken bu alanda ilk adımlar atılmış ve çok kötü koşullar altında oldukça yoğun bir işçi grubunun çalıştığı Ereğli kömür bölgesi için iki kanun çıkarılmıştır.

Böylece o günlerde geçim ve çalışma şartları bakımından korunmaya en çok muhtaç bulunan bölge kömür işçilerinin durumlarının düzeltilmesi amaçlanmıştır.

Zamanın İktisat Bakanı meclis görüşmeleri sırasında bu işçilerin durumunu şu sözlerle ifade etrnişti: "Bizimkilerin halini arzedeyim. Hepsi çılak, hepsi açtır. Hatta üzerlerinde bir mintan bile yoktur. Karadeniz sahillerinden gelen, ameleliği kendilerine sanat ittihaz eden müslüman biçarelerin orada yatacak yerleri yoktur. Bunlara 80 kuruş gündelik verilir. Fakkat 40 kuruşu ekmek. parası olarak kesiliyor..." B.M.M. Zabıtları, Cilt 10 , s. 30 vd.

İlk olarak 28 Nisan 1921 tarih ve 114 sayıl "Zonguldak ve Ereğli Havza-i Fahmiyesinde mevcut kömür tozlarının amele menafî̀ umumiyesine olarak fürühtuna dair Y.anuı" çıkarılmıştır. Bu Kanunla Zonguldak ve Ereğli kömür bölgesinde üretim sırasında ortaya çıkan ve işletmece terkeđilmiş bulunan 'kömür tozlarının açık artırma yoluyla satılarak tutarının iş̧iler yararına kullanılrnası sağlanmıştır.

Bunun hemen arkasından Ereğli kömür bölgesi maden iş̧̧ileri hakkında uygulanmak üzere 10.9.1921 tarih ve 151 sayll "Ereğli Havza-i Fahmiye maden ameledinin hukıkuna müteallik Kanun" çıkarılmıştır.

Bu kanun da uygulama alanı ve işçilere tanıdığı haklar bakımından sınırlı olmakla birlikte çıkarı!dığı devir için sosyal politika açısından çok önemli bir anlam taşımıştır.

Bu kanunu, kapsamı Zonguldak Ereğli kömür madenlerinde çalışan ve çalıştıranlarla sınırlı ilk iş kanunumuz olarak nitelemek mümkündür.

151 sayılı Kanunla Ereğli kömür bölgesinde işveren ve işçi ilişkileri düzenlenmiş ve emek sermayeye karşı korunmuştur. Kanun zorla çalıştırmayı yasaklamış, çalışına süresi, asgari ücretler, en küçük işe alınma. 
yaşı ve işçi eğitimi konularında emek yararına hükümler getirmiştir. Öte yandan işverenlere, iş̧̧i koğuşları ve hamamlar yaptırma yükümü konulmuştur.

Kanun çalışma sürelerini günde 8 saatle sınırlandırmış; fazla çalışma için iki kat ücret ödenmesini öngörmüştür. Kanunda asgari ücretlerin devlet, işçi ve işveren üçlüsünce saptanması esası konulmuştur. Kömür madeninde çalışmaya kabul yaşı "18 yaş" ile sınırlandımlmıştır. Fazla çalışma işçinin isteği ile mümkün olacaktır. Bu hükümlerle o günün şartlarına göre ileri sosyal normlar getirilmiş oluyordu. Özellikle çalışmaya kabul yaşının 18 olarak saptanmıs olması, Dünya'nın belli başlı ülkeleri arasında ilk kez Türkiye'de gerçekleştirilmiş oluyordu. Kanunun işçi kovuşları yapılması şeklindeki hükmü uygulamada geniş yorumlanarak işçi konutları yapımı yoluna da gidilmiştir.

151 sayılı Kanun sosyal güvenlik bakımından önemli hükümler getirmiştir. Bu kanunla:

a) İşverenler hastalanan, kazaya uğrayan işçileri ücretsiz olarak tedavi ettirmeye, bunu sağlamak için maden yakınında hastane açmaya ve doktor bulundurmaya mecbur tutulmuştur. Sağlık kurum ve personelinin sayısı, nerelerde bulunacağı, ortak kurumların giderlerinin madenciler arasinda nasıl bölüneceği bir tüzükle saptanmıştır.

b) İşverenlerin iş kazalam halinde işçiye, ya da kaza ölümle sonuçlanmışsa ailesine, tutar yargı organlarınca saptanacak bir tazminat ödemesi esası konulmuştur. Kazanın işverenin kusurundan doğması halinde Kanun ayrıca işverenden para cezası alınmasını gerektirmektedir.

c). Kanunun getirdiği en önemli tedbirlerden biri de, maden işçileri için "ihtiyat ve teavün sandiklarn"nın kurulmasının ve bu amaçla bir yönetmelik çıkarılmasının öngörülmüş olmasıdır.

Sözü edilen yönetmelik "Amele Birliği ve İhtiyat ve Teavün Sandlkları Talimatnamesi” adıyla 22.7.1923 günü çıkarılarak, kömür madenlerinde "ihtiyat ve teavün sandıkları" kurulmuştur. Bu sandıklar kanun gereği "Amele Birliği" adıyla birleştirilmiştir.

Sandıkların finansman kaynaklarını esas olarak işçi ve işverenlerin, ücret üzerinden eşit oranda ödeyecekleri primler teşkil etmekteydi. Bu sandıklamn ayrıca bağışlar, işçilerden kesilen ceza ve gündelikler, maden şartnamesi gereğince bazı madencilerin işçi payı olarak hükümete ödemeleri gerekli paralar gibi ek finansman kaynakları da vardı.

Yönetmeliğe göre sandıkların üye işçilere sağlayacakları yararlar şunlard1: 
1 - İs kazaları ve hastalıklar durumunda yardım yapılması. Bu işçilerin sözü edilden durumlarda tedavileri işverenlerin sağllk tesislerinde yapılacağındąn burada sö2. konusu olan yardım, iş̧̧ilerin çalışmadıklan sürede geçimini sağlamalamna yardımcı olacak bir sosyal gelirin sağlanmasiydi.

2 - Muhtaç durumdaki iş̧i ailelerine yardım yapılması,

3 - Ödünç para verilrnesi,

4 - İş̧ilerin konut edinmek amacıyla kuracaklar konut kooperatiflerine kredi sağlanıması,

5 - İşçilerin ya da aile fertlerinin ölümü durumunda cenaze giderlerinin karşılanması.

$\mathrm{Bu}$ sandiklar ve Amele Birliğinin kuruluşu ile, kapsamı belirli bölge ve kişilerle sınırlı da olsa, 'Türkiye'de ilk sosyal sigorta uygulamasina başlanmış oluyordu. Çünkü Amele Birliğinin karşıladığı riskler sinırlı olmakla birlikte işverenlerinn sağlık tesisleri de dikkate alındığında, bu risklerle sosyal sigortaların karşıladığı riskler arasında büyük benzerlikler vard.. Amele Birliği de sosyal sigortalar gibi zorunluluk ilkesine dayanmaktaydı. Birlikçe sağlanan yararlar bazı istisnalar bulunmakla birlikte, sosyal sigortalarda olcluğu gibi, işçiler için bir hak teşkil etmekteydi. Birliğin finansmanı sosyal sigortalarda olduğu gibi asıl olarak iş̧i ve işverenden düzenli biçimde alınan primlerle sağlanmaktaydı.

Gerçi Amele Birliği yukarda değinildiği üzere iş̧i ücretlerinden kesilen cezalar, maden şartnamesi gereğince bazı madencilerin iş̧̧i hissesi olarak hükümete ödeyecekleri paralar ve bağışlar gibi ek finansman kaynaklarına da sahiptir. Fakat bunların miktarı esas finansman kaynağı olan primlere oranla önemsizdir. Kaldı ki bir takım para cezalarn, bağışlar, bugünkü Sosyal Sigortalar Kurumu'nun gelir kaynaklam arasında da gösterilmiştir.

Türkiye'de sosyal 'sigorlalar kurulup geliştikçe, Amele Birliğinin Zonguldak. kömür işçilerinin sosyal güvenliğini sağlamada temel kurum olarak rolü giderek azalmıştır. Birlik bu gün üyelerine ek haklar sağlayan ve sosyal sigortalammızda mevcut boşluklarn doldurmaya yönelik bir ek sosyal güvenlik kurumu niteliğini almıştır. Ancak, Sosyal Sigortalar Kurumu çerçevesinde hastalık sigortasının Zonguldak maden iş̧ilerini de kapsadığı 1976 yılına kadar. Amele Birliği sağladığı öteki yararlar dışında üyelerine şu temel yararları da sağlamaktaydı:

1) İş̧ilere, henüz sosyal sigortalaṇn kapsamina girmeyen, iş kazalan ve meslek hastalıkları dışmdaki genel yararlanma ve hastalık halle- 
rinde çalışmadıkları günler için gelir sağlanması. Amele Birliğince bu hallerde iş̧̧lere sağlık yardımı yapılmamaktaydı. Çünkü bu yardımlar işverenlerin 151 sayılı Kanun uyarnnca kurmak zorunda olduklan sağlık tesislerince yapilmaktaydl.

2) İ̧̧verenin işçiler için kurdúğu sağlık kurumilamnın kuruluş giderleri dışındaki genel giderlerine $1 / 5$ oranında katılarak bu kurumlardan işçiler gibi aile fertlerinin de yararlanmalarının sağlanması.

Sosyal Sigortalar Kurumunun hastalık sigortası yönünden de Zonguldak maden iş̧ilerini kapsamasıyla bu yararlar sosyal sigortalar kurumunca sağlanmaya başlandığından Amele Birliği, yukarıda da değinildiği gibi, saf bir ek sosyal güvenlik kurumu niteliğini aldı.

151 sayılı Yasa hükümleri yukarıdaki şekilde uygulamaya konulurken Yeni Türkiye'de sosyal politikaya duyulan ilgi azalmıyor, artıyordu.

Atatürk’ün önderliğini yapmiş olduğu ve ilerde Atatürk'ün kurmuş olduğu bir partiye dönüşecek olan "Anadolu ve Rumeli Müdafaai Hukuk Grubu" 1923 yılı seçim beyannamesinde, genel sağlık ve sosyal yardıma ilişkin kurumların düzeltileceği, bunların sayılarının artırılacağı ve işçileri koruyucu kanunların çıkamlacağı ilan olunuyordu.

Aynı yıl, İzmir'de açılışı Atatürk tarafından yapılmış olan Türkiye İktisat Kongresinde, iş̧̧i grubu olarak katılmış olan delegeler çalışma hayatı ve işçi haklan konularında önemli taleplerde bulunma fırsatı buluyorlardı.

21 Ocak $1925^{\prime}$ te hafta tatili kanunu çıkarılarak resmi dairelerle, sınai ve ticari özel kurumlarda çalışanlara haftada bir gün dinlenme hakkı tanınmıştır. Daha sonra 1935 yılında Ulusal Bayram ve Genel Tatiller Hakkındaki Kanun'la, hafta tatili pazar gününe alınmış ve bazı istisnalar dışında cumartesi 13 'ten sonra başlamak üzere 36 saate çıkamlmıştır. Haftada 6 günden fazla çalışılması yasaklanmıştır.

Cumhuriyet devrinde 1926 ylında Mecelle kaldırılarak Borçlar Kanunu kabul olunmuştur. Bu tarihten 3008 sayılı İş Kanununun yürürlüğe girdiği 1937 yılına kadar geçen dönem içinde, 151 sayılı Kanunun dışında kalan alan ve yerlerde işçi ve işveren ilişkileri Borçlar Kanunu ile düzenlenmiştir. 151 sayılı Kanunun kapsamı dışında kalan alan ve yerlerde 3008 sayılı İs Kanununun kapsamına girmeyenler için, bu durum 1937 yılından sonra da devam etmiştir.

Borçlar Kanununu sosyal politika açısından Mecelle'ye göre daha olumlu karşlamak mümkün ise de, aslında bu Kanun da bireyci ve liberal bir anlayıs taşımaktadır. Borçlar Kanununun genel sorumluluk kuralı klasik hukuk anlayışına uygun olarak kusur esasına dayanmaktadır. 
Atatürk Döneminde çıxarılmış sosyal içerikli önemli kanunlardan biri 1930 tarihli Umumi Hıfsizsıhha Kanunudur. Bu Kanun başka düzenlemeleri yanında kadın, çocuk ve bütün işçilerin korunmasına iliş̧kin hükümler de taşımaktaydı. Bu Kanunla

a) hamile kadınların ċoğumdan önce ve sonraki 3 er haftada,

b) 12 yaşından küçüls çocukların sınai işlerde ve madenlerde,

c) 12-16 yaşlar arasındaki çocukların gece mesaisi ile günde 8 saatten fazla çalıştırılmaları yasaklanmıştır. Öte yandan belirli sayıda işçi çalıştıran işyerlerinde işçilere hastalık, kaza ve analık hallerinde işverence sağlık yardımı yapılması öngörülmüş̧ür. Ancak bu durumlarda iş̧̧inin ücretinin işverence ödenmeye devam edileceği Kanunda yer almamıştır. Fakat 1926'da çıkarılan Bırçlar Kanununda, uzun süreli hizmet aktinde hastalık, askerlik ve benzeri sebeplerden dolayı kusuru olmaksızın çalıહ̧amadiğı nispeten kısa bir süre için işçinin işverenden ücretini isteyebileceği hükmü yer almaktaydu. Ancak bu sürenin ne olacağı kanunda belirtilmediği için uygulamada güçlükler ve hukuk çatışmalar çıkmıştır.

Cumhuriyet devrinde 1930 yllından sonra sosyal sigortalara benzeyen fakat kapsadığı kişiler ve: riskler bakımından dar sınırlı olan birtakım emeklilik ve yardımlaşma sandıklarının kuruluşu ile ilgili kanunlar çıkarilmiştır.

Yeni Türk Devletinin ilk yıllarında, Türkiye'de 151 sayılı yasa dışında bir genel iş kanunu çıkarılması konusunda çalışmalar başlatılmıştır. Bu çalışmalar sonucu 1924, 1929 ve 1932 yıllarında hazırlanmiş bulunan üç tasarı kanunlaşamamıştı. Bu tasamlara liberal bir anlayış havası hakimdi.

1930'lu yıllarda özelli)zle 1934 ten sonra girişilen sanayileşme çabası sonucu Türkiye'de bir işçi kitlesi ve emek piyasası doğmuş ve genişlemeye başlamıştı. Bu şartlarda yurt çapında sermaye-emek ilişkilerinin düzenlenmesi, bu yönde ilerde doğabilecek olumsuz gelişimlerin önlenmesi artık gerekli olmuştu. Öte yandan Türkiye Atatürk'ün direktifiyle 1932 yılında Uluslararası Çalışma Teşkilatı'na girmişti. İşte bu şartlar altında 1934 yılında hazırlanan b:r tasarn 8.6.1936 da kanunlaşarak 3008 saylı İş Kanưu doğmuş ve 1937 yılında yürürlüğe girmiştir.

Bütün bu çalışmalar Avrupa ülkelerinin gelişim aşamasında olduğu gibi işçi grubundan, alttan gelen baskı ya da zorlamalar sonucunda yapılmamış; hükümetler kendiliğinden iş̧̧i haklarını korumanın ve işçi işveren ilişkilerini düzenlemenin çabası içinde olmuşlardır. Bu durum Atatürk döneminde sosyal pclitikaya verilen önemin büyüklüğünü bize yansıtacak niteliktedir. Atatiurk'ün 3008 sayılı İs Kanunu tasarisının hazır- 
lanması sırasında çalışmalarla yakından ilgilendiği ve tasan taslağında el yazısıyla düzeltmeler yaptığı söylenir.

Çıkarılmış olan 3008 sayılı İş Kanununun amacı, çalışan ve çalıştıranlar arasındaki ilişkilerin düzenlenmesi, çalışma koşullarının düzeltilmesi, iş̧̧i hakları ve iş̧̧i sağlığının korunması idi. Kanunda yer alan, işte güvenlik ve sağllk kurallar, çalışma süreleri, kadın ve çocuk iş̧ilerin korunması ile ilgili hükümlerle Umumî Hıfsızsıhha Kanununun açtığı çığır daha geniş bir anlam kazanmaktaydı.

Bugün yürürlükten kaldırılmış bulunan 3008 sayılı İs Kanununun getirdiği çalışma düzeni ve diğer yenilikler üzerinde durmak konumuz çerçevesinde mümkün değildir. Ancak, Kanunun burada değinmek istediğimiz bir başka yönü sosyal sigortalar konusundaki hükümleridir. 3008 sayılı İş Kanunu ile ilk kez Türkiye'de modern sosyal sigortaların kuruluşu öngörülmüştür. Kanun, kurulacak sigorta kolları, bunları yürütecek organ, kuruluşun şekli (dereceli olacağı), öncelik sırası, ilk kurulacak sigorta kollarnnı tarihi, sosyal sigortalara girişin zorunlu olacağı, sosyal sigortaların kapsam ve uygulama alanı hakkında genel ilke ve esaslar koymuştur. Türkiye'de sosyal sigortaların kuruluş ve gelişimi bu ilkelere göre gerçekleşmiştir. Ancak uygulamada, özellikle araya İkinci Dünya Savaşının da girmiş olması nedeniyle, kuruluşta gecikmeler: olmuştur. $\mathrm{Bu}$ gecikmeler önceden sezilmiş olmalı ki, İş Kanunu işverenleri, kadın iş̧ilere doğumdan evvel ve sonra belirli süreler izin vermeye ve bunlardan iş yerinde belirli süre fiilen çalışmış olanların yarı ücretlerini ödemeye, işten doğan hastalık hallerinde iş̧̧ileri tedavi ettirmeye ve iş̧̧ilerin bu sebeple çalışamadıklarn günler için gene yarn ücretlerini vermeye mecbur tutmuştur. Kanunda bu risklerin sosyal sigortalar ya da başka kurumlarca karşlanmaya başlandığı oranda işverenlerin bu yükümden kurtulacakları belirtilmiştir. Böylece sosyal sigortalar kuruluncaya kadar sosyal güvenlik bakımından mevcut boşluk mümkün olduğu ölçüde giderilmek istenmiştir. Ancak, bu maddenin uygulanabilmesi için gerekli tüzük çıkarılmadığı için, bu haklar gerçekte yalnız kağıt üzerinde kalmıştır. Bunda şüphesiz Türkiye'nin İkinci Dünya Savaşı nedeniyle savaş ekonomisine girmiş olmasının rolü büyük olmuştur.

3008 sayılı İş Kanunu ile çalışanların bir bölümü korunmuş oluyordu. Tarım kesimi Kanunun kapsamı dışında tutulmuştu. Öte yandan fikir işçileri ile çalıştırdığı işçi sayısı bakımından belirli bir büyüklüğün altında kalan işyerlerinde çalışanlar Kanunun kapsamına alınamamıştı. O günün şartlarında ilk' kez çıkarılan bir iş kanununun kapsamının bu şekilde sınırlandırılmış olması, sadece gerçekci olmakla açıklanabilir. Özellikle bu Kanunun o günün şartlarında tarım kesiminde uygulanması olanaksızdı. Günümüzde yaklaşlk 50 yll sonra iş kanunun uygulama alanının tarmm 
dışında kural olarak, hizm€t aktiyle çalışanların bütününü kapsayacak şekilde genişletilebilmiş olmasına rağmen, tarım kesiminde çalışanların hâlâ kapsanamamış olması yia da bu kesimde çalı̧̧anlar için özel bir iş kanununun çıkarılamamıs bulunması bu gerçeği ifade etmektedir.

3008 saylı İs Kanunu grev ve lokavti yasaklamıştı. 1930'lu yıllarda Dünyada ve Türkiye'de egemen olan devletçi ve müdahaleci ekonomi anlayışı ve politikaları karşısında başka türlü düşünülmesi mümkün olamazdı. Kaldı ki o ylllarda henüz sanayileşmesini gerçekleştirme yoluna girmeye çalışan bir ülkede: böyle bir tutum sadece gerçekci olmakla da açıklanabilinirdi. Bu nedenlerden esasen 1933 yllında ceza kanununda yapilmış olan bir değişiklikle grev ve lokavt yasaklanmı̧ bulunuyordu.

3008 sayılı Kanunda iş̧̧i işveren arasındaki uyuşmazlıkların (tek başl, toplulukla is ihtilafları) ekonomi politikasına hakim olan bu anlayıs ve tutuma uygun olarak, zorunlu tahkim yoluyla çözümlenmesi ve bu yoldan iş̧̧i haklarının korıunması amaçlanmıştı.

1938 yılında Cemiyetler Kanununda yapılan değişiklikle "sosyal sınuf esasına göre" cemiyet kurulması yasaklanmıştır. Bu kanunla Türkiye'de (1946 yilındaki yeni bir değişikliğe kadar) sendikalarnn kuruluşu engellenmiş oluyordu. Anciak bu düzenlemenin asıl amacı işçi ve gerçek sendikacılık hareketinin durdurulması değil, savaş havasının estiği sonra da bir Dünya Savaşının başladığı yıllarda, ülkeyi komünizm ve faşizm gibi ideolojik siyasal dıs akım ve etkilere karşı korumaktı.

Atatürk bu tehlikeleri daha önceki ylllarda görmüş, ulusun bütünlüğünü korumak, diştan g€lecek komünist, faşist ideolojilere göre bölünmesini engellemek gereğini duymuştur. Bu nedenle Atatürk halkı sadece çalışma alanlarına ayrılmıs, dayanışması gereken meslek grupları halinde görüyor; sınıf kavramı ve sınıf çatışmalarını reddediyor; sosyal politika ile adil bir sosyal düzén kurulmasını ve halk gruplarının çıkarlarının dengelenmesini amaçliyordu.

Atatürk 20 Nisan 1931 'de yayınlanan bir beyannamesinde bu konuda şöyle diyordu: "Türkiye Cumhuriyeti halkını ayrı ayrı sınıflardan mürekkep değil fakat ferdi ve içtimai hayat için iş bölümü itibariyle muhtelif mesai erbabına aynlrnıs bir camia telakki etmek esas prensiplerimizdendir".

Atatürk'e göre, "çiftçiler, küçük sanat erbabı ve esnaf, amele ve iş̧̧i, serbest meslek erbabı, sanayi erbabı, tüccar ve memurlar Türk camiasını teşkil eden başlıca çalışma zümreleridir."

Atatürk sınai alanda alınan bu sosyal politika tedbirleri yanmda, tarım alanında çok zor şartlarda çalışanların da korunması gerektiğinin bi- 
lincindeydi.' Atatürk 1 Mart 1922 de Türkiye Büyük Millet Meclisinin Üçüncü Toplanma Yllı açıs konuşmasında günümüz diliyle "Türkiye'nin gerçek sahibi ve efendisi, gerçek üretici olan köylüdür. Öyleyse herkesten daha çok refah, mutluluk ve servete hak kazanan, lâyık olan köylüdür" demişti.

Ancak, Türkiye'nin ve özellikle tarım kesiminin o zamanki yapısı nedeniyle tarım alanlarında çalı̧̧anların yalın sosyal politika tedbirleri yoluyla korunması mümkün ve yeterli olamazdı. Tarım alanlarında çalışan korunmaya muhtaç geniş kitlelerin sosyal durumlarının düzeltilmesi verimlilik ve üretimi artırıcı, çiftçi ürünlerinin değer pahasına satılmasını sağlayıcı tedbirlerle mümkün olacaktı.

Atatürk bu konuda, yukarda değinilen açış konuşmasında, bugünün diliyle şunları söylemişti: “... Milletin çiftçiliktęi emeğini, çağdaş ekonomik tedbirlerle en yüksek seviyeye çıkarmalıyız. Köylünün çalışması sonunda elde edeceği emek karşllı̆̆ın, kendi yararına yükseltmek, ekonomi politikamızın esas ruhudur. Bu nedenle bir taraftan çiftçinin çalışmasını geliştirecek, daha yararlı hale getirecek bilgiyi verip, onun teknik araçları kullanmasını sağlayarak makinanın yaygınlaşmasına çalışırken; diğer yandan emeğinin sonuçlarından yüksek seviyede yararlanması için gerekli ekonomik tedbirlerin alınması zorunludur. Şimdiye kadar yapılan yolsuzluklar, çağdaş teknik araçların olmayışı, pazarlama şeklinin çiftçiden yana bulunmaması ve Hükümetin kanunlarla çiftçiyi koruyamaması gibi engellerin bütünüyle ortadan kaldırılması gerekir."

$\mathrm{Bu}$ nedenle 1924 yllından sonra bir yandan tarımın modernleştirilmesi, tarımsal ürünlerin artırılması; öte yandan başka tedbirlerle tarım alanında çalışanların durumlarının düzeltilmesi çabasına girildi. Bu çerçevede başlıca şu tedbirler alındı:

Ağır bir vergi olarak çiftçiyi çok güç durumda bırakan aşar vergisi 1925 yılında kaldırıldı. 1926 da medeni kanunun çıkarılmasıyla, belirli şartlar içinde devlete ait (miri) toprakların mülkiyetinin çiftçilere devredilmesi ve bunların toprak ve böylece servet sahibi kılınması sağlandı.

1924 yılında, çiftçilerin kooperatifleşmesini teşvik ve desteklemek amacıyla İtibar-ı Zirai Birlikleri, günümüz diliyle tarımsal kredi birlikleri kanunu çıkarıldı. 1925 yılında İstanbul Zahire Borsasi kurularak bu ürünlerde fiyat istikrarının sağlanması ve çiftçinin ürününü çok ucuz fiyatlarla elinden çıkarmasının engellenmesi amaçlandı.

Devlet bu tedbirler dışında tohum ve hayvan ıslah istasyonları kurarak; çiftçiye fide, kaliteli tohum ve damızlık hayvanı dağıtarak; tarım okulları açarak tarımsal üretimi artırmaya ve çiftçileri refaha kavuşturmaya çalışıyordu. 
Bu tedbirlerle tarımsal ürün ve tarmmsal gelirlerde önemli artışlar sağlanmıştı. Ancak 1929-30 Dünỳa Krizine doğru tarmmsal ürünlerin fiyatları sınai ürünlere göre çok daha hızlı düşmüştü. Öte yandan 1932 yıInda iklim şartları nedeniyle çols kötü ürün alınmış́tı. Bu şartlarda çiftçilerin durumu ve ülke ekonomisi sarsılmıştı.

Bu durum hükümeti yeni tedbirler almaya yöneltti. 1932 yilında buğday fiyatlarının desteklenerek çiftçinin gelirinin düzeltilmesi amacıyla Ziraat Bankası bünyesiinde bir fon kuruldu. Sonra da 1935 yılında çiftçilerin kredi ihtiyaçlarının karşıllanması, ürünlerini yok pahasına elden çıkarmalarının engellenmesi amacıyla Tarım Satıs Kooperatifleri ve Birlikleri ile Tarım Kredi Kooperatiflerinin kurulması yoluna gidildi. Bunu izleyen 1938 yllında Toprak Mahsülleri Ofisi kuruldu.

Öte yandan 1934 yılında İskan Kanunu çıkarıldı. Bu Kanunla köylünün toprak sahibi kılınması ve geçimini sağlayacağı, kendine ait olduğunu bildiği bir temel servete kavuşturulması amaçlaniyordu. Ayrica Kanunda, çiftçilere çift hayvanı, alet, edevat, tohumluk, ahır ve samanlık sağlanmaSı öngörülmüştü. 1937 yılında Devlet Su İsleri Teşkilatı kuruldu.

Atatürk döneminde alman ve yukarıda açıklanan sosyal politika tedbirleriyle bu dönemde kurulan kurumlar varlıklarını aynen ya da değişik biçimde günümüze kadar sürdürmüş ve zamanla gelişerek günümüz düzenlemelerinin temellerini oluşturmuşlardır. Bu durum söz konusu tedbirlerin ne denli bir ileri görüş ve gerçekçilik ile alınmış olduklarının bir göstergesidir.

\section{KAYNAKLAR}

Afetinan, Devletçilik tlkesi ve Türkiye Cumhuriyetinin Birinci Sanayi Plán 1933. Ankara 1972.

Dilik, S.: Türkiye'de Sosyal Sigortałar, İktisadi Açıdan Bir Tahlil Denemesi, Ankara 1972.

Ekin, N.: Endüstri tlişkileri. Istanbul 1976.

Karal, E.Z.: Atatürk'ten Düşünceler, 3. Baskı, Ankara 1969.

Kazgan, G.: Atatürk Döneminde Tüxk Tarımı, Para, Kasım 1981, Sayı 6. s ? v C.

Kuran, E.: Atatürkçülük Üzerine Denemeler, Ankara 1981.

Talas, C.: Sosyal Ekonomi, Ankara 1979; Sosyal Politika, Ankara 1867. 